\title{
MODEL OF IMPROVING PERFORMANCE THROUGH HUMAN CAPITAL, ORGANIZATIONAL LEARNING AND SOCIAL CAPITAL IN THE REGIONAL SECRETARIAT OF SEMARANG REGENCY GOVERNMENT
}

\author{
Nola Atresianilova ${ }^{1 *}$, Moch. Zulfa $^{2 *}$
}

* Affiliation:

${ }^{1,2}$ Magister Management Program, Islam Sultan Agung Islamic University

\begin{abstract}
:
The purpose of this study is to analyze the effect of human capital on social capital, the effect of human capital on performance capital, the effect of organizational learning on social capital, the effect of organizational learning on performance, and the effect of social capital on performance. While the benefits of this research include theoretical benefit i.e. the development of human resource management theory, especially related to the assessment of problems affecting service professionalism, while the practical benefits are able to give results that can be used by leaders to design human capital, learning organization and social capital so that the organization's goals can be achieved. The research was explanatory research, i.e. research that explains the effect of independent variables on dependent variable. The population in this research was employee in the Regional Secretariat of Semarang Regency Government involving 170 people. The sample of research was determined using purposive sampling, i.e. employees who have working period $>2$ years, so that it was obtained as many as 120 employees as samples. The data were collected by using questionnaires, while data analysis was conducted by using SEM analysis. The result of analysis showed that there is influence of human capital on social capital, influence of human capital on performance capital, influence of organizational learning on social capital, influence of organizational learning on performance, and influence of social capital on performance. Equation model also has fulfilled the criterion of goodness of fit. Based on the result of the research, it can be concluded that human capital has an effect on social capital, human capital has an effect on performance, organizational learning has an effect on social capital, organizational learning has an effect on performance and social capital has an effect on performance.
\end{abstract}

Keywords : Human Capital, Organizational Learning, Social Capital, Performance 


\section{INTRODUCTION}

Performance is the appearance of employees work both in quantity and quality. It can be either individual or group work performance (Rosidah, 2010). Organizational performance is the result of complex interactions and performance aggregation of a number of individuals within an organization. To determine the factors that influence (determinant) individual performance, assessment of performance theory needs to be done. In general, physical and non physical factors greatly affect. Various physical environmental conditions greatly affect employees' condition in their work. In addition, physical environment conditions will also affect the functioning of non-physical environmental factors. On this occasion, our discussion focuses on the non-physical environment, i.e. conditions that are actually very inherent with company's managerial system. According to Prawirosentono's (2009) work, an employee's performance will be good, if the employee has high skill, willingness to work, proper rewards / wages and hope for the future. Theoretically, there are three groups of variables that influence work behavior and individual performance, namely: individual variable, organizational variable and psychological variable. The group of individual variable consists of the variables of ability and skill, personal background and demographics.

According to Mayo in Rachmawati (2012), human capital or human resources consists of five components, namely individual ability, motivation, leadership, ability to adjust to the organization, and ability to work in team. Each component has an important role to realize human capital which will have an important impact on the progress of a company. These five components make an important contribution to human capital. Individual ability, motivation, leadership, adaptability to environmental change and the ability to work together are chains that build human resources toward productive human capital capacities. According to Mitchell in Timpe (2008), in his research he stated that human capital is a lifeblood in intellectual capital and the source of innovation and improvement, but is a difficult component to measure.

Organizational learning can result in: customer value enhancement through new or improved product and service delivery, development of new activity opportunities, development of new or improved model processes or activities, error reduction, disability, waste, and associated costs, improving sensitivity and cycle performance, increasing productivity and effectiveness of the use of all resources owned by the organization, and improving the performance of an organization in fulfilling its social responsibility. The success of the workforce depends on increased personal learning opportunities and the practice of new skills. Leadership success depends on access to this type of opportunity. Organizations engage in personal learning through education, training, and opportunities for growth and development. These opportunities can be job rotation, salary increase for achievers and skillful. On-the-job training is an effective way of saving costs for cross-unit training and making better connections between organizational needs and priorities. Education and training can be taken in several forms such as computer and web-based learning and distance learning. Individual learning provides four more benefits to the organization: increasing adherence, satisfaction, and versatility of the workforce in an organization, cross-functional learning, knowledge asset development, and environmental improvement for innovation. 
In running its business, a company must use various capitals. It can be financial capital, technology, human capital (human resources), and natural resource capital. This forms of capital not only functions as a company asset but also as an instrument as well as a goal in the development of the company. Thus, in order for the company to grow then the question is how to maintain and increase social capital so that all other forms of capital have maximum benefits. The social capital within a company is characterized by a mutual social interaction between employees and management and among them. This form of interaction is based on a deeprooted belief in an organizational culture and social ethics. Because of trust, there arises an employee entity (management and non-management) who shares a common sense of honesty, discipline, togetherness, and the importance of hard-smart work. The employees indicate their individual willingness to prioritize the company's entity decisions. Every employee must understand that social capital is a commitment of every individual to be open, trusting and responsible. In addition, with the increasing quality of human resources, it is expected to form a sense of togetherness, solidarity, and also the responsibility of progress together. Therefore, every company should be encouraged to establish itself as a learning organization. It is an organization in which members of an organization continually expand their ability to learn and develop their own potential. In this case, corporate leader plays an important role in developing social capital in his company.

The resources of civil servant in the General Section of the Regional Secretariat of Semarang Regency have different backgrounds, giving different outputs in behaving. This condition certainly has an impact on the working atmosphere within the organization that ultimately affects performance. Winarno et al (2012) in his research showed that human capital and organizational learning significantly influence the performance moderated by organizational culture. Similarly, Widodo and Widjajanti (2014) in their research stated that human capital and organizational learning affect performance. While Ramanda and Muchtar (2014), Alviani and Purnamasari (2014) in their research showed that human capital and organizational learning have no effect on performance. Based on the above, this research is conducted to find out the model of performance improvement through human capital and organizational learning and social capital in Regional Secretariat of Semarang regency Government.

\section{LITERATURE REVIEW}

\section{The Effect of Human Capital on Social Capital}

According to Totanan (2004), companies will be able to achieve different performance if managed by different people, meaning that individual differences will produce different work results. Therefore, the existence of human resources needs to do good management by paying attention to each different potential for different treatment. Fitz-Enz (2000) in Setyanto (2004) stated that human capital is a combination of three factors, namely: the character or nature of a person brought into the organization, including intelligence, physical ability, positive attitude, reliability, and commitment, developing their abilities, supported by cognitive factors or intellectual abilities, psychomotor attitudes and factors, as well as the ability to work together in teams manifested by good communication with members of an organization. 
Mayo (2010) stated that human resources consist of several components, namely individual ability, motivation, leadership, ability to adjust to organizational climate, and ability to work in team effectively. These components have different roles in creating human resources in a company so as to determine the value of a company. The five components include: Individual abilities including ability, experience, network, effort in realizing the achievement of the work, the ability to develop themselves; and the ability to bring his environment to move forward; Individual motivation including aspirations, ambitions, work motivation and productivity; Leadership including how the leadership model, and organizational management capabilities; Climate Organization can be organizational culture that can affect individuals in the work, as well as the ability to work in team, that is the ability to realize cooperation to achieve goals.

Human capital can be interpreted as a resource in a person who can be a potential in supporting his work. Human capital can be seen from several indicators such as ability or capability, motivation, leadership spirit in a person, and ability in teamwork. They are all factors that can be seen as easily identifiable in an employee.

Successful organizations will depend on how individuals do with all their ability to jointly realize the goals of the organization. In today's dynamic world of work, where tasks are increasingly being worked out in teams, flexibility is crucial. Therefore, it needs capable resources to realize the performance in accordance with company goals. Thus, it can be formulated hypothesis as follows:

$\mathrm{H} 1: ß 1 \neq 0$, meaning that there is a positive significant effect of human capital on social capital

\section{The Effect of Human Capital on Performance}

Every job requires a person to carry it out as expected. This is because every job is always related to employee salary, while the work will be related to company progress. One's performance will be directly proportional to job satisfaction. A person who has achieved performance will feel job satisfaction (Kaplan, 2001: 43). Someone will increase their performance if he gets appreciation for what is done to his work. The appreciation can be in the form of promotions, opportunities to increase knowledge, or additional salary or other rewards so that the capability, dedication and professionalism get a decent reward. These aspects are very important in supporting an employee to realize the quantity and quality of work encountered with the target set. JG Gardner in Hasibuan (2008) stated, performance can be measured by the appreciation of agencies or leaders for the work of an employee that is realized with the provision of compensation, awards or opportunities to develop his knowledge. Performance measured based on the achievement of quantity and quality of work will increase employee motivation to do better when getting appreciation.

According to Dharma (2009), human capital is an accumulation of capabilities, capacities and opportunities owned by the members of an organization. Capability is the ability of organizational members to do something both capacity and opportunity to achieve desired goals. Capacity is more focused on what the members of an organization can do, while the opportunities are more available to the members of an organization to get personal rewards including salaries, bonuses and so on as a result of their capacity utilization, so that capability is formulated as opportunity $\mathrm{x}$ capacity. 
What can be produced by human beings can not be separated from their capitals such as knowledge, expertise and other values that enable the movement of financial and physical capitals. These capitals are human capital which must be created for the creation of innovation. The research conducted by Princess (2014) showed that human capital affects work performance. Based on the description, it can be arranged hypothesis as follow:

H $2: ß 2 \neq 0$, meaning that there is a positive significant effect of human capital on performance.

\section{The Effect of Organizational Learning on Social Capital}

Peter Senge (1999) argued that effective organizational learning requires 5 (five) dimensions in realizing an ever-innovating organization: employee personal skills, mental models, communicated vision, team learning, and systemic thinking. These five dimensions of Peter Senge need to be manifested in an organization member in carrying out its work. These five dimensions of organizational learning should be realized to improve the quality of human resources, because through organizational learning and the ability to adapt to all forms of change supported by competent human resource capabilities, the organization will grow and gain the trust of the environment.

Fukuyama (2009) convincingly argued that Social Capital plays a very important role in the functioning and strengthening of modern society. Social capital plays as a requirement for human development, economic development, social, political, and democratic stability. In it is a cultural component for the life of modern society. As the corruption and deviations occurring in different parts of the world and especially in developing countries of Asia, Africa, and Latin America, one of the main determinants is the low social capital growing in society. Weak social capital will dim the spirit of gotong royong (togetherness), exacerbate poverty, increase unemployment and crime, and hinder any efforts to improve population welfare.

The term social capital has long been discussed in the literature. The term first appeared in 1916 when there was discussion about building a learning center within an organization (Cohen \& Prusak, 2001). The concept of social capital was raised as a scientific discourse by James S. Coleman (1990). Discussion about the concept of social capital was lately more warm after the emergence of Putnam's research (1993) describing that organizational learning plays an important role in realizing social capital. Thus, the hypothesis can be formulated as follow: $\mathrm{H} 3: \beta 3 \neq 0$, meaning that there is a positive significant effect of organizational learning on social capital.

\section{The Effect of Organizational Learning on Performance}

This study employed organizational learning theory presented by Senge (1990) who devides organizational learning into 5 dimensions: system thinking, mental models, personal mastery, team learning and shared vision (building shared vision) and dialogue / discussion as added by Marquardt (1996).

According to Stata (2011), a company that conducts organizational learning is a company that has expertise in creating, taking, transferring knowledge, and modifying its behavior to reflect its new knowledge and experience to its employees. Baldwin (2005) stated that all employees continue to observe the environment in an effort to obtain important 
information in the change of strategies and programs needed to gain profit for the company, while environmental changes, procedures and evaluation techniques are continually improved. Thus the hypothesis can be formulated as follow:

$\mathrm{H} 4: ß 4 \neq 0$, meaning that there is a positive significant effect of organizational learning on performance.

\section{The Effect of Social Capital on Performance}

Islam has a strong foundation for realizing social capital in doing work, since social capital is a part of habluminannas. According to Mintarti (2003), Islam has a commitment of affairs with God and with society. In the life of Islamic society, it has some social capitals such as ta'awun (mutual help), mutual responsibility (takaful) and solidarity. Societies with good social capital will be able to develop the organization based on the principles of equality, mutual appreciation, respect and joint efforts to achieve established goals based on religious norms, as well as social and legal norms.

Man is basically good. Therefore, it is hoped in society life to always be prejudiced both and avoid somethings related to defamatory. Philosophical teachings are manifested in the daily life of the Prophet Muhammad, especially in trade so that he is known as al-Amin (a trusted person). In the Qur'an, it is mentioned that the affairs of worship (aqeedah) and muamalah are a mutually supportive business. The affairs of man's relationship with God and human relationships with human beings must go hand in hand. The manifestation that a person believes in God is well connected with His fellow creatures.

Many prophet's hadiths emphasized the importance of social capital, both among Muslims and fellow human beings (see Mintarti, 2003). Anas RA. stated that the Prophet PBUH said, "There is no perfect faith in any of you so that you love your fellow Muslims, as you have loved yourself." An-Nu'man Basyir RA. said: Allah's Messenger (may peace be upon him) said: "The parables of the believers who love and bless one to each are like one body, when one of its limbs is sick, it spreads the suffering throughout the body, until it feels hot and can not sleep. "This kind of attitude applies also to fellow human beings. Jarirbin Abdillah RA.said: Rasulullah SAW said, "Whoever does not love his fellow human beings, then he is not beloved of God."

Another determinant of performance is organizational learning; that universities have the expertise in creating, taking, and transferring knowledge, and modifying its behavior to reflect on its new knowledge and experience. By continuing to do organizational learning, it is expected that universities can improve their performance (Baldrige National Quality Program, 2010). Thus, the hypothesis can be formulated as follow:

H $5: \beta 3 \neq 0$, meaning that there is a positive significant effect of social capital on performance.

\section{RESEARCH METHOD}

This is explanatory research i.e. research which aims to explain the effect of independent variable on dependent variable (Soelaeman, 2004). The population in this research was employees in Setda Kab Semarang involving 170 employees. The number of samples was chosen as many as 120 people with a criterion of staff with more than 2 years working period. A 
questionnaire was directed at the respondents. The form of questionnaires was a closed question that had to be answered by the respondents, related to human capital, organizational learning, social capital, and employee performance. It also used observation to explore the problems that exist in the General Section of Setda Semarang Regency related to the performance of employees. In this research, the analytical technique used was Structural Equation Modeling (SEM) using AMOS in capital development and Imam Ghozali (2005: 3) testing. This model is a second generation of multivariate analysis technique that allows to examine the correlation among complex variables.

\section{FINDINGS AND DISCUSSION}

1. Analysis of Confirmatory Factor

a. Variabel Exogen where it has 3 latent variables i.e. the variables of human capital, organizational learning and social capital as seen on table 1 below.

Table 1. Exogen Variable Confirmatory Testing

\begin{tabular}{|c|l|l|l|l|}
\hline No & $\begin{array}{l}\text { Goodness of fit } \\
\text { index }\end{array}$ & Cut of value & Analysis Result & $\begin{array}{l}\text { Model } \\
\text { Evaluation }\end{array}$ \\
\hline 1 & X $^{2}$-Chi square & Kecil & 191.272 & Good \\
\hline 2 & $\begin{array}{l}\text { Significancy } \\
\text { Probability }\end{array}$ & $\geq 0.05$ & 0.084 & Good \\
\hline 3 & GFI & $\geq 0,90$ & 0.969 & Good \\
\hline 4 & AGFI & $\geq 0,90$ & 0.954 & Good \\
\hline 5 & TLI & $\geq 0,90$ & 0.971 & Good \\
\hline 6 & CFI & $\geq 0,90$ & 0.955 & Good \\
\hline 7 & RMSEA & $\geq 0,08$ & 0.021 & Good \\
\hline 8 & CMIN/DF & $\leq 5,00$ & 1.894 & Good \\
\hline
\end{tabular}

Source: AMOS ouput

The above table explains that the model can be stated fit meaning that the model has been in accordance with the data. The overall conclusion of the model is acceptable and the next step was analyzing the estimate parameter. The regression results from the latent variables are all significant as well as the covariance between the latent variables is also significant. So it can be concluded that professionalism can be explained by 3 latent variables of human capital, organizational learning and social capital. Regression result is shown in table 2 below. 
Table 2. STANDARDIZED REGRESSION WEIGHT FACTORS OF HUMAN CAPITAL, ORGANIZATIONAL LEARNING AND SOCIAL CAPITAL

\begin{tabular}{|l|l|l|l|l|l|l|l|}
\hline & & & Estimate & S.E. & C.R. & P & Label \\
\hline x15 & $<---$ & h_cap & 1.000 & & & & \\
\hline x14 & $<---$ & h_cap & 2.599 & .881 & 2.950 & 0.000 & par_1 \\
\hline x13 & $<---$ & h_cap & 2.749 & .692 & 3.972 & 0.000 & par_2 \\
\hline x12 & $<---$ & h_cap & 1.866 & .457 & 4.083 & 0.000 & par_3 \\
\hline x11 & $<---$ & h_cap & 1.124 & .388 & 2.896 & 0.000 & par_4 \\
\hline x25 & $<---$ & p_org & 1.000 & & & & \\
\hline x24 & $<---$ & p_org & .658 & .146 & 4.691 & 0.000 & par_5 \\
\hline x23 & $<---$ & p_org & .545 & .142 & 3.848 & 0.000 & par_6 \\
\hline x22 & $<---$ & p_org & 1.231 & .086 & 14.340 & 0.000 & par_7 \\
\hline x21 & $<---$ & p_org & .609 & .140 & 4.348 & 0.000 & par_8 \\
\hline x35 & $<---$ & m_sosial & 1.000 & & & & \\
\hline x34 & $<---$ & m_sosial & .898 & .076 & 11.857 & 0.000 & par_9 \\
\hline x33 & $<---$ & m_sosial & .496 & .103 & 4.815 & 0.000 & par_10 \\
\hline x32 & $<---$ & m_sosial & .323 & .067 & 4.799 & 0.000 & par_11 \\
\hline x31 & $<---$ & m_sosial & .474 & .100 & 4.740 & 0.000 & par_12 \\
\hline
\end{tabular}

Source: AMOS output

\section{Endogen Variable}

The measurement model of confirmatory factor of endogenous variable was used to test the suitability of the model (fit) to the data used in this study. Endogenous variable is performance. The analysis resulted chisquare value equals to zero $(0.000)$, meaning that the model is stated fit.

While the calculation of Standardized Regressioin Weight Factor for Endogen Variables (performance) consisting of 4 indicators have Critical Rate (CR) or t-count is larger than t-table, so that the observed variables have significant correlation with the latent variable (performance). More about Standardized Regressioin Weight Factors for Endogenous Variables are as listed in Table 4.4. below.

Table 3. Standardized Regression Weight Factor Of Performance

\begin{tabular}{|l|l|l|l|l|l|l|l|}
\hline & & & Est1mate & S.E. & C.R. & P & t tabel \\
\hline y1 & $<---$ & kinerja & 1.000 & & & & \\
\hline y2 & $<---$ & kinerja & 4.602 & .797 & 5.774 & $* * *$ & 1.6601 \\
\hline y3 & $<---$ & kinerja & 2.882 & .815 & 3.536 & .001 & 1.6601 \\
\hline y4 & $<---$ & kinerja & 4.830 & .861 & 5.609 & $* * *$ & 1.6601 \\
\hline
\end{tabular}

Source: AMOS ouput

3. Structural Equation model (SEM)

The calcualation result with AMOS program obtains as follow: 
Tabel 4. Goodness of Fit Index

\begin{tabular}{|l|l|l|l|l|}
\hline No & Goodness of fit index & Cut of value & Analysis Result & Model Evaluation \\
\hline 1 & X $^{2}$-Chi square & Kecil & 813.877 & Marginal \\
\hline 2 & Significancy Probability & $\geq 0.05$ & 0.063 & Good \\
\hline 3 & GFI & $\geq 0,90$ & 0.929 & Good \\
\hline 4 & AGFI & $\geq 0,90$ & 0.917 & Good \\
\hline 5 & TLI & $\geq 0,90$ & 0.913 & Good \\
\hline 6 & CFI & $\geq 0,90$ & 0.942 & Good \\
\hline 7 & RMSEA & $\geq 0,08$ & 0.021 & Good \\
\hline 8 & CMIN/DF & $\leq 5,00$ & 4.884 & Good \\
\hline
\end{tabular}

Source: AMOS ouput

Based on Table 4.5, it can be explained that the test of the model hypothesis is in accordance with the data or fits to the data used in the study. Based on Table 4.5, it can be seen as follows:

a. $\mathrm{X}^{2}$ (Chi-Square)

The result of analysis obtained X2 (Chi-Square) 813.877 which has small value with degree of freedom 116 at probability 0.063 . Based on this result, the proposed model is acceptable fit (statistically identifying a good match), or there is no significant difference between the observed data and the proposed model.

b. GFI (Goodness of Fit)

Goodness of Fit denotes the overall fit of the model, where the value is between zero and one. The closer to zero means poor fit while the closer to one means perfect fit. The result showed GFI of 0.929 which means good, because it is greater than the required GFI i.e. 0.90.

c. TLI (Tucker Lewis Index) and AGFI (Ajusted Goodness of Fit)

TLI and AGFI show comparison between research models and baseline of the research, which are non statistical measures. The results showed that TLI resulted 0.913 and AGFI was 0.917. They are greater than the proposed TLI $(\geq 0.90)$ and approximate from the recommended AGFI (0.90), it can be concluded that it has good results.

d. CFI (Comporative Fit of Index)

CFI is a measure to identify the fit rate of a model that is between zero and one, where it is closer to one meaning the highest fit level. The result showed CFI of 0.9428 which is in a good category, because it is more than the recommended CFI i.e. $\geq 0.90$

e. RMSEA (The Root Mean Square Error of Aproximation)

The RMSEA shows goodness of fit when the model is estimated in the population. The result showed RMSEA of 0.021 or smaller than the recommended $\leq 0.08$. This indicates that the model is acceptable.

f. CMIN/DF is also used to measure the fit of a proposed model. In this study, it obtained CMIN / DF of 4,884 smaller than the proposed CMIN $\leq 5.00$. Based on this test, it can be known that the results of research in accordance with the proposed model and then the hypotheses of research variables were performed. 


\section{The Effect of Human Capital on Social Capital}

The result of calculation using the computer can know the amount of effect of human capital to social capital that equals to $\beta=0.704$, so it resulted simple regression equation Social Capital $=0.704 \mathrm{HC}+\mathrm{e}$. This regression equation has a unidirectional relationship pattern, meaning that increasing human capital will increase social capital, as evidenced by the positive sign of the regression coefficient.

The output as shown in the regression model yields a value of 2,353, while the t-table value with the degree of freedom (df) 116 : $\alpha=0.05$ obtained t-table equals to 1.6540 . So $t$ count is greater than t-table value. This means Ho was declared rejected, and Ha was accpeted.

Thus, the hypothesis that states the effect of human capital on social capital, is statistically declared true, and rejects the hypothesis that states no effect of human capital on social capital. This study supports the result of previous research conducted by Widodo and Kesi Wijayanti (2014) who stated that if an organization does not encourage the ability of its resources then human resources will not be motivated to realize its performance. Another study according to Winarno (2012) showed that developing human resources will essentially provide support in developing his personality skills including in fostering social capital.

\section{The Effect of Human Capital on Performance}

The result of calculation using the computer can know the amount of effect of Human Capital on Performance that equals to $\beta=0.86$, thus it generated a simple regression equation Performance $=0.86 \mathrm{HC}+\mathrm{e}$. This regression equation has a unidirectional relationship pattern, meaning that an increase in human capital will improve employee performance. This is evidenced by a positive sign of the regression coefficient.

The output as shown in the regression model yields a value of 2,536, whereas the t-table value with the degree of freedom (df) 116 : $\alpha=0.05$ obtained t-table equals to 1.6540 . So $t$ count is greater than t-table value. This means Ho is declared rejected, and Ha accepted.

Thus, the hypothesis that states the effect of human capital on performance, is statistically declared true, and rejects the hypothesis that states there is no effect of human capital on performance. It shows if an organization / human resource in work is oriented to the development of human capital, it will improve the quality of work and have a better desire to orient work quantity so that it affects the development of continuity with the fulfillment of qualified standards in work and gets feedback as well as ability to carry out work on time. Conversely, if the individual or organization is not oriented to learning, it will cause a high risk both in quantity and quality of HR performance.

\section{The Effect of Organizational Learning on Social Capital}

The calculation result using computer can be known that the effect of organizational learning on social capital is $\beta=0.628$. Thus, it resulted simple regression equation Social Capital $=0,628 \mathrm{P}+\mathrm{e}$. This regression equation has a unidirectional relationship pattern, meaning that good organizational learning can improve employee performance. This is evidenced by the positive sign of the regression coefficient. 
The output as shown in the regression model yielded a value of 2,298, while the t-table value with degree of freedom (df) equaling to 116; $\alpha=0.05$ obtained t-table value of 1.6540 . Thus, $\mathrm{t}$ count is greater than t-table value. This means Ho is declared rejected, and $\mathrm{Ha}$ is accepted.

Thus, the hypothesis that states the effect of organizational learning on social capital, is statistically declared true, and rejects the hypothesis that states no effect. It shows that if individual / organization has ability and willingness to share knowledge to fellow member, hence it will give effect to quality and quantity of human resource work. In addition, if an organization / human resource maintain the quality of interaction communication and attempt to create new knowledge in working, it will tend to meet the standards of qualifications in work. Conversely, if within an organization there is no willingness and ability to share knowledge, then the ability to recognize the new knowledge will be lost and at risk for HR performance.

\section{The Effect of Organizational Learning on Performance}

The calculation result using computer can be known that the effect of organizational learning on performance is $\beta=0,817$, so it resulted simple regression equation of organizational learning $=0,817 \mathrm{P}+\mathrm{e}$. This regression equation has a unidirectional relationship pattern, meaning that good organizational learning can improve the performance of employees. This is evidenced by a positive sign of the regression coefficient.

The output as shown in the regression model yields a value of 2.553 , while the t-table value with degree of freedom (df) equaling to $116 ; \alpha=0.05$ obtained t-table value of 1.6540 . Thus, $\mathrm{t}$ count is greater than t-table value. This means Ho is declared rejected, and $\mathrm{Ha}$ is accpeted.

Thus, the hypothesis that states the influence of organizational learning on performance, is statistically stated true, and rejects the hypothesis that states no effect. It shows that if an organization / human resource upholds integrity and always opens to fellow members in work then it tends to have a good quality of work and work-oriented quantity. In addition, if an organization / human resource has consistency and a strong belief in carrying out the task, it will meet the standards of work qualifications and always on time. Conversely, if a person's trust is lost then it is possible not to open and will lose the spirit to work and high risk for HR performance.

\section{The Effect of Social Capital on Performance}

The result of calculation using the computer is known the magnitude of the effect of social capital on performance i.e. $\beta=0.924$, resulting in a simple regression equation Performance $=$ $0.924 \mathrm{MS}+\mathrm{e}$. This regression equation has a unidirectional relationship pattern, meaning that high social capital will improve employee performance, as evidenced by the positive sign of regression coefficient.

The output as shown in the regression model yields $t$ value of 3.492 while the $t$-table with degree of freedom ( $\mathrm{df}$ ) equaling to $116 ; \dot{\alpha}=0.05$ obtained t-table value of 1.6540 . Thus, $\mathrm{t}$ count is greater than $\mathrm{t}$-table value. This means Ho is declared rejected, and Ha is accepted. 


\section{CLOSING}

\section{Conclusion}

Based on the descriptions on data analysis and managerial implications, it can be summarized as follows:

1. The variable of human capital has an effect on performance, meaning that performance will come true if employees have human capital that serves the organization well and have loyalty to the organization.

2. The variable of human capital has an effect on social capital, meaning that human resources will affect how to utilize twork environment to serve the community.

3. The variable of organizational learning has an influence on performance. Performance will be created if employees have a passion in working, have a desire to achieve the target so that employees will work as well as possible, which is one form of organizational learning.

4. The variable of organizational learning has an influence on human capital. Organizational support will contribute to social capital.

5. The variable of human capital has an influence on performance, meaning that performance will be created if there is good communication between employees, so that the existing job description is actually manifested in the work environment.

\section{Suggestions}

Based on the conclusions of the research results on the effect of organizational commitment, motivation, and communication on the professionalism of public services, the suggestions that can be submitted are as follows:

1. The need for appraisal of Employment Assessment Checklist (DP3) which really pay attention to aspects of the implementation of work performed by employees.

2. The need for provision of computers with good specifications and telephone networks that support with internet access so as to facilitate employees in working and in communicating with other parties.

3. Leaders need to hold supervision attached to each employee by monitoring and evaluation so as to know how far employees in carrying out the task given.

4. Communication fellow employees should not only be done while in the work environment alone, but followed up outside the work activities so as to create a compact working relationship.

5. The relationship of leadership with subordinates should not only be tasks, but there must be two-way communication so that subordinates have the opportunity to convey aspirations to the leadership. 


\section{REFERENCE}

Arikunto, Suharsimi. 2010. Prosedur Penelitian, Suatu Pendekatan Praktek. Jakarta: PT. Rineka Cipta.

Baker, W. dan J. Sinkula. 2009. The Synergetic Effect of Market Orientation and Learning Orientation on Organizational Performance. Journal of the Academy of Marketing Science, Vol. 27 h. 411-427.

Barney, J. B. 2010. The Resource Based View of Strategy: Origins, Implications, and Prospects. Editor of Special Theory Forum in Journal of Management No. 17 h. 97-211.

Barney, J. B. dan D. N. Clark. 2007. Resource-Based Theory: Creating and Sustaining Competitive Advantage. Oxford University Press.

Dessler. 2012. Developing Management Skill (Terjemahan). Jakarta: PT. Gramedia.

David, Fred R. 2009. Manajemen Strategis. Jakarta: Salemba Empat.

Dwiyanto, Agus. 2008. Reformasi Kebijakan Publik. Jurnal Manajemen.

Ferdinand, Augusty. 2003. Sustainable Competitive Advantage: Sebuah Eksplorasi Model Konseptual. Research Paper Series.

---------. 2006. Structural Equation Modelling Dalam Penelitian Manajemen. Semarang: BP Undip.

Ghozali, Imam. 2013. Model Persamaan Struktural Konsep dan Aplikasi dengan Program Amos 21.0. Semarang: BP Undip.

Handoko, T. Hani. 2008. Manajemen Sumber Daya Manusia. Jakarta: Sinar Baru Algesindo

Hasibuan. 2008. Manajemen Sumber Daya Manusia. Jakarta: Sinar Baru Algesindo

Keban, J. T. 2003. Indikator Kinerja Pemerintah Daerah: Pendekatan Manajemen dan Kebijakan. Makalah, Seminar Sehari. Yogyakarta: Fisipol UGM.

Koentjaraningrat. 1990. Manajemen Organisasi. Jakarta: Gramedia

Lupiyoadi, Rambat. 2004. Manajemen Pemasaran Jasa. Jakarta: UI Press

Luthans, F. 1998. Organizational Behavior, Seventh Edition. International Edition, New York: McGraw-Hill Companies, Inc.

Mayo, T. A., John R. Deckop. 2010. Evolution of Concept and Practices in Personnel Administration / Human Resources Management. Journal of Management, Vol. 12 No. 2 h. 223-241.

Mahsun, Mohamad. 2006. Pengukuran Kinerja Sektor Publik. Yogyakarta: Penerbit BPFE.

Mas'ud, Fuad. 2004. Survai Diagnosis Organisasional Konsep dan Aplikasi. Semarang: BP Undip.

Mintarti, Nana 2003, Modal Sosial, Pembangunan Komunitas Madani dan Peran Amilin. Jakarta: Gramedia 
Muslikh. 2013. Peran Pembelajaran Organisasional Visioner dalam Meningkatkan Kinerja Organisasi. Jakarta: Universitas Yarsi.

Pitt, L. F. dan Kannemeyer. 2000. The Role of Adaptation in Microenterprise Development: A Marketing Perspective. Journal of Developmental Entrepreneurship, Vol. 5 No. 2.

Robbins dan Judge. 2002. Perilaku Organisasi, Buku 1, Cet. 12. Jakarta: Salemba Empat.

Rosidah, 2005. Manajemen Sumber Daya Manusia. Jakarta: Erlangga

Ruky, Achmad S. 2010. Manajemen Kepegawaian Karyawan. Jakarta: UI Press

Simamora, Henry. 2008. Manajemen Sumber Daya Manusia. Yogyakarta; BPFE

Soelaeman, Wahid. 2004. Analisis Data dengan SPSS. Yogyakarta: Kanisius

Steers, R. M. 2003. Organization Effectiveness, A Behavioral View, Good Year Publishing Company, diterjemahkan oleh Magdalena Jamin. Jakarta: Erlangga.

Sugiyono. 2009. Statistika untuk Penelitian. Bandung: Alfabeta

Suharto, Edi. 2007. Kebijakan Sosial sebagai Kebijakan Publik: Peran Pembangunan Kesejahteraan Sosial dan Pekerjaan Sosial dalam Mewujudkan Negara Kesejahteraan di Indonesia, Bandung: Alfabeta

Swasta, Basu. 2004. Manajemen Organisasi. Yogyakarta: Kanisius

Widodo. 2011. Model Pengembangan Evaluasi Strategi. Semarang: Unissula Press. 2011. Model Teoretikal Dasar Aliansi Stratejik Sebagai Strategic Knowledge Menuju Keunggulan Bersaing Berkelanjutan. Ekobis Vol. 12 No. 2 h. 223-234.

Yin, Robert K. 2009. Metodologi Penelitian Kuantitatif. Jakarta: Gramedia 